\title{
Tropical Gothic: Radiance Revisited
}

\author{
Allison Craven \\ Department of Humanities, James Cook University
}

Directed by Rachel Perkins in 1998, Radiance is a film that deserves a sequel. The fates of Mae, Cressy and Nona after they head off up the road in Mae's old car is a cinematic mystery that intrigues me more the longer I live in North Queensland, the place in which both Radiance the film and its antecedent, Radiance the play (Nowra 1993), are set. This essay does not attempt to investigate, much less solve this mystery, but instead deepens it by considering aspects of location, setting and narration in the film, which was co-scripted by Perkins and Nowra, as well as the process of transposition $_{1}$ from play to film (Nowra 2003). Setting, used to realise the gothic aspects of the drama, marks the transposition between these otherwise similar versions of Radiance. Even local audiences fall for the film's mesmerising re-creation of the sub-region of North Queensland ${ }_{2}$ selected as a setting and in spite of minimal allusions even to Queensland in the dialogue. The house, the canefields, the beach and the island are 'regional sign systems' ${ }_{3}$ (Whitlock 1994) that present a convincing depiction of the place in which we dwell; some even say these features look familiar. Perkins (2003) tells how she set the film in Queensland to honour the setting of the original play, and she speaks of travelling to Queensland to gain the "atmosphere" of the place, and to choose locations. In fact, the locations chosen were far from North Queensland: Agnes Water, Rosedale, Childers, Bundaberg and Hervey Bay, as well as Max Film Studies in Sydney ${ }_{4}$, while Nora Island "is a fabrication although some people swear they recognize it," says Nowra (2000, xiii). Radiance therefore comes to stand for the remarkable power of film to suggest a reality, and for the importance of location in telling a story on film. $\underline{5}$

In addition, the illusion of North Queensland in Radiance holds deeper resonances in the film's narrative, and these are the subject of this paper. That is, the illusion of place seems homologous with the illusion of 'home' around which, I argue, the drama is constructed. While, as Alison Butler (1992) says, "geographical space . . inhabit[s] discourses that are ostensibly about other things" (414), equally in the comic drama of Radiance the narrative curls through gothic passageways that evoke the disturbing history of a region, North Queensland. In this it challenges the prevailing mythos of the pre-Mabo cinema of Queensland in profound and provocative ways. Take for example, Albert Moran's (2001) description of John Ruane's feature, Queensland, made in 1976, and George Miller's Mad Max 2: The Road Warrior, made in 1982, where "Queensland is an Eden held out to the characters as they undergo a narrative of events that are situated elsewhere. ... . [A] goal, a heaven 
on earth, that the characters hope to reach in the future" (24). He adds that, as "garden or promised land, the place can be seen to function as part of a much broader myth, known since classical and biblical times, but more recently incarnated in the image of the frontier in white settler societies" (Moran 24). Radiance does invoke this mythology but rewrites it in a post-Mabo framework (Collins and Davis 2004; Kelly 1998), whereby Queensland, I argue, becomes an anti-Eden, an un-Paradise figured by abundant, gothic canefields and made emblematic in the burning, amid the cane-fires of the region, of a house that was once called home. 6 Home, according to James Ferguson (1997) is the place to which one is bonded by kinship, but in Radiance home becomes an alternative mythic destination. A search for a 'true home' is pursued both in Nona's quest to place her mother's ashes on Nora Island, and in the apparently homeless state in which the sisters confront the future at the end of the film. In the first section of this essay, I discuss the sources of the dystopian mythos of home in Radiance. Then, in further sections, I comment on how the film, in particular, evokes a haunted sense of home through four elements of mise-en-scene: Nona's performance of Madam Butterfly, which is the mythic kernel of Radiance; the role and realization of the house in which the sisters reunite; the depiction of canefields as exterior setting; and the effects of diegetic and non-diegetic music on these gothic features. Finally, referring to the genesis of the play, I conclude with reflections on some aspects of the tropical setting in North Queensland that evoke specific meaning in Radiance.

\section{Myths of Home}

While it is the first feature film to have been made by an Indigenous woman ${ }_{7}$, Radiance is less comfortably grouped with Beneath Clouds, The Fringe Dwellers, and Yolngu Boy, in a genre about Indigenous people negotiating poverty and historical discrimination, even though it shares features with such films. Radiance is more in the style of a woman's film of the 'sisters' sub-genre, like Hannah and her Sisters, In Her Shoes, or Hilary and Jackie. As Nona, Cressy and Mae reunite for the funeral of their mother, their tensions ignite comically in a dispute over how to dispose of her ashes. The women are the focus of almost the entire action, even though the film includes some minor male characters who do not have an on-stage presence in Radiance the play. Nona, the youngest, has been drawn homewards by the discovery she is pregnant, unaware that her mother has just died. Her desire for her mother is redirected into returning her ashes to her 'true home', Nora Island, seen across the water in the film. Cressy, an international opera star, arrives from London and her anxiety to leave and thus escape the house and memories of her mother is tempered by her desire to see Nona, for reasons that are made harrowingly apparent in the dénouement. Meanwhile, Mae, the eldest, has been there all along, nursing their dying mother. Resentments deepen as a tortured family 
history emerges. Cressy and Mae do not share Nona's affection for the house or the late mother. They admonish Nona as the "lucky one" who was not removed by authorities, signaling their connection to the Stolen Generations. Conflicting desires combust when Mae reveals that the house was never theirs and that they are about to be evicted by the landlord, Harry, their mother's lover. When, in revenge, they decide to burn it to the ground, a powerful family secret is revealed concerning Nona's birth, and the destruction of the house therefore forms a spectacular background to the destruction of a more profound illusion in their relationships.

The paradigm of returning home is all the more powerful because the women are Indigenous. The spectre of colonial dispossession and of loss of land and ancestry therefore looms over their story. Even so, Nowra and Perkins claim that the film is about "any three sisters reuniting for their mother's funeral, where the past is an issue but the women's Aboriginal identity is not" (Collins and Davis 127), an approach that emerged in the original workshopping of the play (Nowra 2000, ix). Furthermore, Perkins (2003) speaks of wanting to make a movie to which "everyone" could relate. However, Collins and Davis suggest that while Radiance "grants Aboriginality the status of an unmarked identity", a status that, they point out, is "usually confined to white masculinity in Australian cinema" (127), Radiance is an "explicitly post-Mabo film" in its attention to "the original act of dispossession of Indigenous land and identity ${ }_{8}$, signified by Nona's desire to return her mother's ashes to the island of her grandparents" as well as the secondary dispossession of assimilation (127). This is in spite of - or because of - what Veronica Kelly sees as the "painful absence" of the "nameless, dead mother" in the play, and her "perceived compliance with imposed power" (96).

The mythos of home is affected by a shift in emphasis between play and film. Kelly describes Radiance the play as "the story of a mother's homecoming to heal her estrangement from the daughter she has not been allowed to know or acknowledge" (163). Kelly is referring to the play's emphasis on Cressy's quest, but in the film Nona's quest is the focus ${ }_{2}$ and the addition to the film of Nona's pregnancy intensifies Nona's quest, in that she desires to give birth in the house in which she was born. The film's more authentic realization of setting enables a more compelling rejection of the colonial ideals of home in which Nona's nostalgias are embedded. Such ideals of home, according to Seamus O'Hanlon (2002) 10 are linked to "childhood memories and feelings of . . . 'the security of a private enclave where one can be free and in control of one's life'" (3). It is an ideal, he argues, that is inextricably associated with colonial traditions, originating from class practices in Britain and Europe, and "transplanted through colonialism ... to the English-speaking world, firstly to North America and 
later to the Antipodes" (7). In colonial Australia, O'Hanlon says, home "was a symbol of the freedoms and opportunities available, at least theoretically, to the colonist" (11). In Radiance, however, home represents not an ideal but a dystopia, a site of violence, discrimination and oppression. Therefore the sisters' destruction of the house at the conclusion of the film becomes a demythologising act, against home and also against mythic, Edenic Queensland.

\section{Retelling Madam Butterfly}

Radiance takes shape as a kind of ghost story. The story is haunted by a number of characters who are either invisible, dead or mythical: Harry, the Mother, the Black Prince (who Nona believes to be her father), and Madam Butterfly, a mythical Oriental woman abandoned by her lover, who materializes in Nona's performance of Cressy's recordings of her signature role as an opera singer in Puccini's Madam Butterfly. By candle-light and dressed in a kimono, Nona performs Cressy's aria, complete with burlesque death-scene. This performance is one of several 'costume changes' as Mae dresses up in their mother's unworn wedding dress, and Cressy changes out of her elegant suit into a sun-dress, all of which Kelly interprets as "theatricalisations of the enigmas of identity and of the mother's sexual and moral roles" (Kelly 168). Nona's Butterfly, however, is also an Oriental theatrical metaphor for the sisters' stories. I interpret Nona's Butterfly by following Marina Heung's (1997) study of the myth of Madam Butterfly in Miss Saigon (first produced in the late 1980s) and Indochine (released in 1992), both works that are contemporary with the genesis of Radiance.

The geisha Cio-Cio San, the archetype of the self-sacrificing mother in Puccini's opera Madam Butterfly, suicides after giving her child to the American wife of her lover Leiutenant Pinkerton. Not only is Cio-Cio San the exemplary 'expendable' Asian woman, according to Heung, but Madam Butterfly is a "foundational narrative" of 'the Orient' figured as "sexualized" and "sexually compliant" (160). Madam Butterfly, Heung argues, is an "exemplary text extolling the female virtues of domestic duty and self-sacrifice, except that these are now figured through the travails of an Asian woman" (164) in an orientalisation of western feminine ideals. As both "displaced wife/mistress and the nonEuropean, [Puccini's] Butterfly is ... doubly Other, and her rivalry with an Anglo-American woman only underscores her marginality in relation to both family and culture" (164-165). The adaptation of Madam Butterfly in the global musical, Miss Saigon, an allegory of the Vietnam War, according to Heung becomes a "restorative drama paradigmatic of the post-Vietnam era", which transforms the myth of Butterfly from an interracial romance to a trope that Heung calls "the family romance of Orientalism", a trope that "reenacts" a "saga of recovering lost fathers" (161). 
The adaptations of the Butterfly mythos in Radiance, play and film, are intriguing. The Japanese nationality of Butterfly and the Indigenous identity of the women of Radiance are obliquely referenced in the sisters' banter about Nora Island, their mother's ancestral home, becoming the site of a Japanese tourist resort. Puccini's (Japanese) Butterfly is later activated by Nona, play-acting Cressy's signature operatic role. This 'playlet' as Kelly calls it, introduces an exoticism that is lampooned as Nona hams up the performance, perhaps because the myth seems farcical when applied to their situation. Not only does their demented mother seem an unexotic replica of Butterfly, but the recovery of fathers is all but futile, so many were the boyfriends visited by the mother. But Radiance is emphatically a story about the recovery and discovery of maternity. Here, as in Heung's reading of Indochine, the story of Butterfly is recast as a mother/daughter melodrama (Heung 172). While the original Cio-Cio San was in conflict with the wife of Pinkerton, there was no estrangement between herself and her child. However, in Radiance and Indochine the betrayal breaks out in relationships between mothers and daughters, through the dead mother's handing over of her two elder daughters to institutions, and through Cressy's concealing that she is the biological mother of Nona. Kelly comments on the 'slip' in Radiance the play, which is replicated in the film, whereby this recasting of the story occurs. She describes how in Puccini's opera, the "powerless, colonized mother of a mixedrace child contemplates killing him rather than surrendering him to his white father; but instead of killing the child (as Nona mis-remembers) Butterfly kills herself, preserving honour in the face of defeat and shame" (Kelly 169, my emphasis). This has the effect of both "reversing the sacrifice Cressy's mother made of her, and reflecting what Cressy herself has had to do by killing her maternal identity to spare Nona the truth" (169). While neither the dead mother nor Cressy have literally suicided, the repression of their maternity has the same effect. Cressy's choice of "a career of performance" (170) as an opera singer is therefore emblematic of her dissimulation. 11 Her offer of money to Nona (in the film; Nowra 2000, p 94) is, Nona later realizes, to finance an abortion (Nowra 2000, p 109), an offer that seems a further echo of Butterfly's plight.

This gothic story of hidden maternity is played out in a gothic setting, a house that has the presence of a non-speaking character in both play and film, and to this I now turn.

\section{Dys-Tropic Home and the Road Out}

There can be no more powerful metaphor for home in a film than a house. The house in which the sisters meet, a ramshackle old Queenslander, complete with lattice, verandahs and tongue-in-groove walls, forms a significant presence in the film. It is described by Collins and Davis as "a far cry from the suburban dream. . . . A shack in the canefields, rather than a haven at the beach, the mother's 
house is a piece of evidence in a long history of perfidy" and it is "alive with unreconciled memories" (127). Referring to the film settings, Nowra (2000) says: "We saw the house as Gothic, haunted by ghosts and the burden of the past", and he explains how "[w]ith slow pans through the house that revealed kitsch images of Aborigines and even a picture of Christ with a burning heart, Rachel was determined to show the potency of the [dead] mother's presence" (xi-xii). The shabby, claustrophobic house suggests the agonies associated with home in the family, and scenes within it are filmed as if the interiors intrude on the sisters' tense reunion, the walls, windows and wall-hangings figured strongly in close-ups and medium shots on the sisters, suggesting Perkins' vision of the house's claustrophobia and hence the presence of the mother. When Mae and Cressy agree to burn the house, the interiors are noticeably diminished compared to earlier scenes, suggesting the power the sisters are experiencing over their mother's legacy. Tensions are lessened between all three women on the verandah, a transitional site closer to Nora Island, where, unlike in the interior, the light is amber and nostalgic.

The strongest subjective view of the house in the first half of the narrative in both play and film is Nona's nostalgic one. Indeed, Nona's encounter with the house resembles what Gillian Whitlock calls a 'child-in-the-house' narrative, which she argues is a feature of regional Queensland discourses (79) (although Whitlock is not referring to Radiance). Noting the abundance of examples in Queensland literature, Whitlock models an example on a David Malouf novel, where the "child-in-the-house narrative makes its way from verandah, through the rooms and down to 'under the house'", a space of the "irrational" that is mythologised as a fairytale forest "as dark as anything in Grimm" (78). In a similar pattern, Nona journeys from upstairs where she revels in raunchily recollecting the mother's sexual history in the rooms, beds and sheets (while Mae associates her mother with the chair in which she died) to her "spooky wailing" and "maniacal laughter" (Nowra 2000, p 112) when under the house, upsetting her sisters who demand she "get back here" (112). In the play these associations are created off-stage by Nona and the under-house is not seen, but Nowra tells how as filmmakers they saw under the house as "the cellar of a gothic film" (xii). Under the house, Nona finds a relic, the black prince's hat, which she incorporates into the fantasy of her parentage, thus finally provoking the first of Cressy's disclosures about the past. In the play, Nona's descent to under the house grants focalization fully to Cressy and Mae, and correspondingly in the film the subjective view of the house becomes theirs when Nona disappears under the house (although the camera also goes under the house). 
Thereafter, the spectacular torching of the house is pure gothic melodrama, with echoes of Bertha Rochester all around. 12 But the cinematic spectacle - apart from the fact that a real house was burned down for the scene (see Featurette 2003) - is emphasized by a musical discourse. As they throw kerosene around, Cressy comments: "this is so operatic", and puts Madam Butterfly on the stereo. The soaring arias accompany the destruction, and therefore the revelations of Cressy's rape and of her conception of Nona. While the house burns, a juxtaposition of elemental forces occurs as Nona desperately plunges across the water to Nora Island with the 'Radiance' urn containing her mother's ashes. As morning comes, and Nona is seen depositing the ashes, then returning to the mainland by boat, the strains of Butterfly give way to non-diegetic chords of 'My Island Home' sung by Tiddas, the same song that Nona has earlier sung to Cressy. The song continues over the end of the film as the apparently homeless women drive away, with Mae and Cressy wearing Nona's wigs. Nona grudgingly acknowledges Cressy as her mother, but the new family relationships born in the tensions of the previous night remain to be explored. As Collins and Davis comment, while the "shame of being the daughters of the anonymous men who visited that hidden house in the canefields is gone forever ... the differences between the sisters/daughters remain" (128).

The burning of the house is a spectacular visual climax to both play and film. It is also a statement about terra nullius, if it is considered that the first settlement by Europeans equated absence of permanent architecture with absence of culture (Ferrier 42). However, Radiance the play does not show Nona spreading the mother's ashes on Nora Island as in the film - although Nowra (2000) mentions that a Queensland Theatre Company production directed by Wesley Enoch did conclude with Nona scattering the ashes (ix) - nor are the women seen reunited in the morning. Instead, the play ends with Mae and Cressy watching the house burn. Kelly concedes that strong closure might be expected to elude a play such as Radiance was in 1993, when "aboriginal right to 'home' yet remain[ed] provisional and dependent on the goodwill of powerful whites" (164). While not much has changed since, the film makes a stronger symbolic statement as the women are seen reunited in the morning and then heading away up the road. In this closing sequence, however, the film skips genres and becomes more intertextual with road movie than with gothic melodrama. Fiona ProbynRapsey (2006) details discourses of the road in feature films about Indigenous people, such as Backroads, The Wrong Side of the Road, Bush Mechanics, Backlash and Beneath Clouds, to mention a few. She suggests that the road movie genre carries images of terra nullius, and that the genre mythologises "'freedom on the road to nowhere'" (Corrigan qtd in Probyn-Rapsey 97). She also notes the presence of road trips in a number of human rights actions on behalf of Indigenous Australians over several decades, such as the Charlie Perkins'-led Freedom Ride of the 1960s, modeled on the US 
Freedom Ride of the 1960s, and Michael Long's 'Long Walk' of 2006. Probyn-Rapsey argues therefore that the road is a contested site in postcolonial discourse, associated with dystopian and poetic narratives, and that it has been adopted at times as a metaphor for reconciliation, even though in many films she says, "Aboriginal mobility appears as a threat to whites, in particular to the State" as it is represented by a white police force (109). Most positively, though, she suggests that the road movie often exhibits the "poetics of 'interval'" (108) as being more powerful than journey or destination. It is precisely this sense of 'interval' that emanates from the closing vision of Radiance as the women take to the road in Mae's car. Neither conclusive nor especially pessimistic, their future is given simply as unknown.

\section{The Music of the Canefields}

The burning of the house in both play and film merges with another spectacle that is distinctly evocative of region: canefields. It is one of the noticeable effects of the play's transformation to film that cane becomes a more visible element of setting. In the play, cane and cane burning are referred to, and the villain Harry Wells is said by Nona to have "the biggest sugar plantation" (Nowra 2000, 23). In both play and film, the women plot to torch the house during the cane burn so it won't be noticed except by Harry, a plan that also defuses audience anxieties about arson. But while the setting for the play is clearly given as "North Queensland" (Nowra 1993, vi; 2000, 4), Act 1 is entirely set in

"the large living room of a wooden house on stilts" with "many shutters" (1993, 1; 2000, 5); and Act 2 is located on "the mud flats" $(1993,35 ; 2000,59)$. Cane is therefore talked about but not seen. Adapted to film, however, cane has visual presence, and Nowra says that the vision of canefields was crucial to the authenticity of a North Queensland setting: "I . . . wanted to make sure we portrayed North Queensland, especially the sugarcane fields, because people always associate Aborigines with the outback rather than the tropics" (Nowra 2000, x) 13 . He adds that, "[w]e wanted Radiance not only to be different but to look different (x, emphasis in original). He does not elaborate as to from what Radiance was to be different but Nowra's preference for non-native plantation crop rather than rainforest as metonym for the 'tropics' seems deliberate, and the meanings are powerful. While the depiction of canefields may have been realist in purpose, the towering cane plantations double as a potent metaphor for the overwhelming power of the plantation economy and colonial culture that has determined the women's lives in association with the region's disturbing racial history. Cane signifies the plantation economy of Queensland that was underpinned for many years by indentured labour. Cane symbolizes the way the women are in every sense alienated from this economy, not residents, not tenants, not progeny or possessors but evictees. Cane therefore looms 
as a symbol of aboriginal dispossession. The manner in which views of cane are incorporated into Radiance creates a gothic effect in the (non-beach) exteriors that is comparable to the gothic interiors in the house.

Thus, in Radiance the film, cane dominates the few sketchy views shown of landscape. First seen through Nona's eyes from the window of the semi trailer as she wends her way north, it recurs as a visual motif throughout. High, abundant cane plantations surround the house and the roads. Even the cover of the published screenplay shows the sisters against a background of cane (Nowra 2000, cover). Cane in fact frames the narrative: an early view of a burning cane field, is followed by the sea at sunrise, and by a morning view of the house, with the road to it passing through towering cane; but in the closing scenes, the cane fields are empty, razed, presumably harvested. In addition, gothic ambience of cane is transmitted by music, most noticeably the traditional songs (by the Saibai Islander Community) that accompany views of the women driving through cane fields on the road to the church. Traditional music in these short but powerful sequences creates strong contrasts with the remaining diegetic and non-diegetic score, especially the music of Butterfly, which is the music of the house, heard diegetically on the stereo and in a non-diegetic piano score over several sequences.

On the way to the church, the objective view of a cane plantation is followed by footage of the car proceeding through tracks in the cane, which then becomes a blurred rush of green. A cut-away to a close-up of a pristine floral bouquet on the coffin indicates arrival at the funeral, at the same moment as the non-diegetic traditional song abates and is replaced by the dreary voice of the priest. The church is a musically-uninspiring place: Nona wails loudly through the service; Cressy, the opera singer, refuses the priest's request to lead the hymn; then the dull strains of "Amazing Grace" are played on the tinny organ, before giving way to the jingle of cicadas as the women walk from the church. The contrasts between home, church and the music of the canefields are potent. Diegetic metal music on the car radio, however, accompanies the sequence following the church service, in which Mae, on a vengeful whim, drives to Harry's house to return his wreath. The camera frames her in close profile against the car window as cane is seen behind her. Later, traditional drum music is heard while the women travel in Mae's car through canefields to the airstrip, and the playfulness of the drumming suggests Nona's playful sabotage of Cressy's escape from their reunion. When her ploy fails and Cressy decides to wait for the next plane home, Nona and Mae air their tensions in the car by arguing over Mae's choice of metal music on the car radio. This pattern of subordination of the music of the canefields to the noise of family angst adumbrates the theme of dystopian home and counters the white-settler myth of Edenic Queensland. 


\section{On the Beach}

According to Kelly, Nowra was inspired to write the play not by cane but by the "tidal mangrove mudflats at Emu Park" during 1987 when he was a writer in residence at Central Queensland University in Rockhampton. Asked some time later to develop a play for Indigenous women actors, he wrote Radiance, which was first performed at the Belvoir Street Theatre in Sydney in 1993. With funding from the Aboriginal Arts Board, the play was workshopped for two weeks by Indigenous actors, who, along with an early director of Radiance, influenced Nowra's writing of these characters (Nowra 2000, viii-ix) as did Nowra's then partner, Justine Saunders, according to Kelly (30). In an introduction to the published play and screenplay, Nowra tells of an early inspiration for Radiance when he stayed at Kinka Beach near Yeppoon, because he "wasn't keen" on Rockhampton, and how in a motel overlooking the sea he was "intrigued" by the tidal mud flats, "that seemed to stretch all the way to Great Keppel Island" (2000, vii). He says that, "it was the sight of an unknown woman walking across the nocturnal mud flats, as they glistened in the moonlight one evening that stirred my imagination" (vii). He relates that some years later, "a friend from Queensland" had told him of caring for her dying mother, and of the funeral that ensued with a "strange and awkward ... reunion of girls who didn't really know each other" as each was the child of a different father (vii). Nowra therefore attributes the genesis of Radiance the play to a meeting of "the image from the mudflats" with "the story of my friend" (vii).

The fictional women of Radiance seem most reconciled in scenes on the beach or, to use Nowra's expression, the "mud-flats". Mud-flats, of course, are what the beach becomes at low tide (although 'mud-flat' does not hold the same mythic resonance of 'fatal shore', mythic here also because of the beach's proximity to Nora Island). On the beach, Mae vents her sadness that her mother didn't love her; Nona sings to Cressy; and the idea to burn the house is unfurled. The beach is also the habitat of another character first introduced in the film--a turtle that washes in on the tide and is found by Cressy and Nona. Nona sees an opportunity to commemorate their mother traditionally, if only she knew how to perform the rituals, which include roasting the turtle. It languishes in the kitchen, until, with the burning of the house imminent, Nona returns it to the beach. It is a curious sequence, and a number of first-time viewers query the fate of the turtle, not noticing what becomes of it, and not understanding its role in the drama.

Presumably few non-Australian or non-North Queensland viewers would know that federal law authorizes only Indigenous people to take turtle as Cressy and Nona do. For those unfamiliar with this law, the story of the turtle is something of an ellipsis, and it became a point of contention in the 
making of the film. Nowra relates an anecdote about a meeting with a funding agency when, presumably in an earlier version of the script, the turtle did not survive:

"Another time I felt as if I were caught in a Monty Python sketch as a bureaucrat argued at considerable length about the treatment of the turtle. I argued that Aborigines kill turtles up north (and turtle is delicious), but the woman, who prided herself on her small-L-liberal devotion to 'getting Aborigines right', kept on saying she thought it was gruesome. Finally I gave in - the turtle wouldn't be killed and it would escape the fire. (Later at a preview a woman came up to me and said 'Oh, I'm so pleased the turtle lived'.) (Nowra 2000, xii).

Nona's rescue and return of the turtle to the sea is comparable to the rescue of her mother's ashes, and both the turtle and Nora Island are strong allusions to traditional culture that also draw attention to racial issues in Radiance. But the subtlety of these allusions in the context of the unmarked presentation of these characters is comparable to the way the setting of the film is unmarked as SouthEast Queensland while strongly alluding to the North; and to the way home seems like home, but it is not; and to the way the mother seems like Nona's mother but is not. This poetic of similarity between the illusion and the hidden 'real' is also threaded to the curious and diffuse titular metaphor of 'Radiance'. With poignant multiple allusions not limited to the spectacles of the house and cane fires, or to the luminous courage of the sisters, a further allusion is explicit in the Radiance tin that Nona finds under the house and uses to store the mother's ashes. Nona likes the smell of the tin, but after Cressy tells her the story of the mother's rape, the first fictional version of Nona's origin, she finds that the tin has "lost the smell of licorice" (1993, 34; 2000, 42 and 115). The Radiance tin therefore comes to signify the sensual, affective experience of loss that prefigures Nona's total loss of her illusory mother.

\section{Conclusion: Revisiting Radiance}

Andre Bazin (1974) argued that the adaptation of plays and novels to film is part of an 'evolutionary' process of cinema, a process he likens to a river eroding away the features of a landscape over a great period of time. While he speaks of cinema in the abstract, this evolutionary figure can well characterize the transitions of texts between forms. From a pre-Mabo story in its genesis as a play, Radiance the film becomes a post-Mabo narrative that is also refocalised from Cressy in the play, to Nona in the film. This process of evolution is also forged through actors' histories in productions. Deborah Mailman and Rachel Maza, for instance, both stars of the film, had also performed in play versions of Radiance; Maza, the film's Cressy, having played Mae in a stage 
production (Tricia Morton-Thomas, the film's Mae, was in her first and only film performance to date). Perhaps this network of actors enmeshed in the evolution of Radiance also contributes to the complex dramaturgy of home and maternity.

In the course of this essay, I have suggested a number of other aspects of this evolution. The gothic aspects of the narrative, so concentrated in the house in the play are also elaborated through images of canefields and a counterpoint of Indigenous and classical song to create a distinct emotional cadence in the film. Familiar regional sign systems of North Queensland, the canefield and the queenslander house are adapted--including a 'child-in-the-house' figure that is associated mostly with Queensland literatures--and enlarged through the reconfiguration of the tragedy of Madam Butterfly. The effect compels the dystopic histories of the women and the region so that Radiance becomes a vivid contestation of the ideals of colonial home, and of North Queensland as Eden and holiday paradise. With the climactic destruction of the house and therefore all the family's secrets and illusions, Radiance, arguably takes a 'new road', pointing the women to a future that seems to affirm terra nullius. Where the road really leads requires a further evolution, a sequel, perhaps. The story would then visit new locations, consigning the mysteries of the dystopian, tropical-gothic home of Radiance to a place along the way.

Acknowledgements: I am grateful to Associate Professor Cheryl Taylor for her generous comments on, and editing of, this paper; and to students of CN2205/3305 Studies in Film and Place in 2007 and CN2203/3303 Women in Cinema in 2005 at James Cook University for their enthusiastic discussions about Radiance.

\section{References}

Bazin, Andre. What is Cinema? Essays selected and translated by Hugh Gray. U of California P, 1974 (first published 1967).

Butler, Alison. "Ndew Film Histories and the Politics of Location." Screen 33.4 (Winter) 1992): 413-426.

Cartmell, Deborah and Whelehan, Imelda eds. Adaptations: From Text to Screen, Screen to Text. London and New York: Routledge, 1999.

Collins, Felicity and Davis, Therese. Australian Cinema After Mabo. Cambridge UP 2004. 112132. 
"Featurette: Radiance". In Radiance . Universal Studios, 2003.

Ferguson, James. Culture, Power, Place. Duke UP, 1997.

Ferrier, Elizabeth. "From Pleasure Domes to Bark Huts: Architectural Metaphors in Recent Australian Fiction." Australian Literary Studies. 13.1 (1987): 40-53.

Heung, Marina. "The Family Romance of Orientalism: From Madam Butterfly to Indochine." In Visions of the East: Orientalism in Film. Eds. Matthew Bernstein and Gaylyn Studlar. Rutgers UP, 1997. 158-183.

Kelly, Veronica. The Theatre of Louis Nowra. Sydney: Currency Press, 1998

Moran, Albert. Queensland Screen: An Introduction. Griffith Uni, 2001

Nowra, Louis. Radiance. Current Theatre Series. Sydney: Currency in Association with Belvoir Street Theatre, Sydney, 1993.

----. Radiance: The Play and the Screenplay. Sydney: Currency, 2000.

O'Hanlon, Seamus. Together Apart: Boarding House, Hostel and Flat Life in Pre-War Melbourne. Melbourne: Australian Scholarly Publishing, 2002.

Perkins, Rachel. "Interviews: Rachel Perkins, Director". Special Feature on Radiance. Universal Studios, 2003.

Probyn-Rapsey, Fiona. "Bitumen Film in Postcolonial Australia." Journal of Australian Studies 88 (2006): 97-109.

Radiance. Dir. Rachel Perkins. Eclipse Films. 1998. (Released on DVD by Universal Studios 2003.)

Whitlock, Gillian. "The Child in the (Queensland) House: David Malouf and Regional Writing." In Amanda Nettlebeck ed. Provisional Maps: Critical Essays On David Malouf. Nedlands WA: The Centre for Studies in Australian Literature, UWA, 1994. pp 71-84. 
1 See Cartmell and Whelehan (1999). They cite Wagner's identification of three types of adaptation: "transposition" where a novel is "'directly given on screen'"; "commentary" where "'an original is . . . altered in some respect"'; and "analogy" where action or "essential context" is changed so that "little of the original is identifiable" (Cartmell and Whelehan p. 8).

2 I base this observation on the reactions of students in my cinema classes at James Cook University in North Queensland in which Radiance is studied in two courses, and many students know the play from its use in school syllabus.

$\underline{3}$ See Whitlock (1994). The epithet 'regional sign systems' is derived from Whitlock, although she is not discussing Radiance or any of the regional signs mentioned.

$\underline{4}$ In the credits, special thanks are noted for the community of Agnes Water, and the fire brigades of Agnes Water, 1770 and Captain Creek, as well as various shire councils for Miriam Vale, Hervey Bay and Isis.

5 The precise place of the settings for Radiance are vague as the instruction that it is set "in North Queensland" is barely qualified within either play or screenplay. Meanwhile, a speech of Nona's in the play that is not transposed to the film about how she once ran away to "Ayr" to go to a rodeo in "Rocky" and left a note for her mother saying she was going to "Cairns" (Nowra 19993, 13; 2000, 18) might bamboozle a North Queenslander as Ayr is nowhere near Rockhampton. Apart from this, the main verbal references to Queensland are in Nona's chastisement of Cressy for not mentioning Queensland in her career publicity.Nona says to Cressy: "It was in the programme - no mention of Queensland. Here. Mum. Mae. Me." (Nowra 1993, 18; 2000, 24); and Nona's film line is slightly varied as "I read an article on you - no mention of Queensland. Here. Mum. Mae. Me. (2000, 99).

6 Other plays by Nowra apart from Radiance that concern or are relevant to native title and terra nullius, include: Crow and Capricornia. The latter is an adaptation of Xavier Herbert's novel set in the Northern Territory (see Kelly 1998).

7 Rachel Perkins was well established as a documentary maker before Radiance, having worked with Imparja Television (producers of Indigenous programs for broadcasting in Alice Springs) before joining SBS and the ABC. In 2002, she co-established the Message Stick Indigenous Arts Festival in Sydney, and in that year, she was also recipient of the Byron Kennedy Award (jointly awarded by 
Kennedy Miller Corporation and the AFI). After Radiance, which was nominated for several major AFI Awards, and for which Deborah Mailman received the Best Actress Award, Perkins made a second feature, One Night the Moon (2001), co-written with John Romeril, and which has also been acclaimed, and received several major awards.

$\underline{8}$ Collins and Davis are referring, of course, to the 1992 Mabo Native Title decision of the High Court of Australia, which overturned the principle of terra nullius, on which colonization was founded.

9 See the explanation for this shift given by Nowra (2000, p xi).

10 It should be noted that $\mathrm{O}^{\prime} \mathrm{Hanlon}$ is not discussing Radiance, but referring to a general notion of 'ideal' home.

11 This rewriting of the Madam Butterfly myth can also be compared with The Fringe Dwellers, in that Trilby, ruing her chances for education, murders her baby. The framework is not directly comparable but there is a sense of tragic sacrifice in Trilby's actions, and a crisis of maternity at least comparable to that in Radiance.

12 The burning of the house is an act of arson suggested by Mae but instigated mostly by Cressy. In the play, Mae has a history of stealing and is on a good behaviour bond. This lends criminality to her desire to burn the house, and Nona comments that she has "a criminal mind", but this aspect of Mae is not transposed to the film.

13 This is not the only Nowra play that features Queensland or cane-Queensland. Whitsunday, a collaboration for the Bicentennary in 1988 was set "on a tropical island in Queensland" (Kelly 35); Byzantine Flowers (1989) is "set on a North Queensland sugar plantation" (36).

[an error occurred while processing this directive] 